used. The case for oral systemic corticosteroids is as yet unproven. Necrotic tissue should be removed. Pneumonia is common in severe cases. ${ }^{7}$

In conclusion, TEN is a rare side-effect of indomethacin therapy. Awareness of this association is important for two reasons: TEN is potentially lethal and indomethacin is widely used in the UK.

JT LEAR

JSC ENGLISH

Department of Dermatology, North Staffs NHS Trust, Stoke on Trent, ST4 7PA, UK

1 Lyell A. Toxic epidermal necrolysis: an eruption resembling scalding of the skin. $\mathrm{Br} \mathcal{F}$ Dermatol 1956; 68: 355.

2 Pye R. Bullous eruptions. In: Champion RH, Burton JL, Ebling FJG, eds Textbook of Dermatology, 5th edn. Oxford: Blackwell Scientific matology, 5th edn. Oxford:

3 O'Sullivan M, Hanly JG, Molloy M. A case of toxic epidermal necrolysis secondary to indomethacin. $\mathrm{Br} \mathcal{F}$ Rheumatol 1983; 22: 47-9.

4 Roujeau JC, Bioulac-Sage P, Bourseau C, et al Acute generalised exanthematous pustulosis. Arch Dermatol 1991; 127: 13.

5 Felix RH, Smith AG, Stevenson CJ. Skin disorders. In: Davies DM ed. Textbook of adverse drug reactions. 3rd edn. Oxford: Oxford Medical Publications, 1985; p 475.

6 Roujeau JC, Guillaume JC, Fabre JP, et al. Toxic epidermal necrolysis: incidence and drug aetiology in France. Arch Dermatol 1990; 126: 37-42.

7 Heimbach DM, Engrav LH, Marvin JA. Toxic epidermal necrolysis. A step forward in treatepidermal necrolysis. A step forward
ment. $\mathcal{J} A M A$ 1987; 257: 2171-5.

\section{Neuroleptic malignant syndrome with normal creatine kinase}

Sir,

Neuroleptic malignant syndrome is an uncommon but life-threatening complication of neuroleptic drug treatment. ${ }^{1}$ It was first described in 1968 but a quarter of a century later, doubts still exist concerning the diagnostic criteria. The syndrome has been characterised as the combination of autonomic dysregulation, muscular rigidity, hyperthermia, confusion, agitation, elevated creatine kinase and leucocytosis. ${ }^{2}$ Serum creatine kinase is considered to be the single most important investigation in diagnosing this condition. ${ }^{3,4}$ We report a case of presumed neuroleptic malignant syndrome based on clinical features, but with a normal creatine kinase which responded to dantrolene.

\begin{tabular}{l} 
Neuroleptic malignant \\
syndrome \\
\hline Clinical features \\
- confusion and agitation \\
- hyperthermia $\left(>38^{\circ} \mathrm{C}\right)$ \\
- tachycar rigidity \\
- tachypnea \\
- autonomic dysregulation \\
Laboratory findings \\
- elevated serum creatine kinase \\
- leucocytosis \\
- mypoxia \\
- myobolic acidosis \\
\hline
\end{tabular}

\section{Case report}

A 54-year-old man with a four-year history of manic depression was transferred from a psychiatric hospital for emergency medical treatment. He was on lithium $700 \mathrm{mg}$ daily, chloropromazine $200 \mathrm{mg}$ tid and had received depot haloperidol $200 \mathrm{mg}$ two weeks earlier. He had been hospitalised for a relapse of his manic depressive illness and seemed to be making good progress. One week after admission, however, he became aggressive and violent over a two-hour period and was noted to be pyrexial.

On examination he appeared dehydrated and was febrile with an axillary temperature of $38^{\circ} \mathrm{C}$; there was no apparent focus of infection. He was producing copious secretions from his mouth but his chest was clear. Muscle tone was increased in all limbs but there were no other neurological signs. Haemoglobin was $10.5 \mathrm{~g} / \mathrm{dl}$, white cell count $14.1 \times 10^{9} / 1(80.4 \%$ neutrophils $)$ platelets $399 \times 10^{9} / 1$. Arterial blood gases showed a $\mathrm{PO}_{2}$ of $10.3 \mathrm{KPa} \mathrm{PCO}$ 4.8 KPa, pH 7.35, $\mathrm{O}_{2}$ saturation of $96 \%$. Urea and electrolytes were normal and the creatine kinase was $35 \mathrm{IU} / 1$ (normal 30-250). In view of his restless and violent behaviour he was immediately sedated with intravenous fluids and intravenous midazolam. He remained pyrexial and there was no improvement in his aggressive behaviour. Daily creatine kinase measurements were normal and urine myoglobin was not detected.

By 48 hours he remained pyrexial and disturbed. Having excluded a septic focus neuroleptic malignant syndrome was postulated, with a normal creatine kinase. Intravenous sodium dantrolene was given at a dose of $1 \mathrm{mg} / \mathrm{kg}$ (six hourly for two days). There was a dramatic response in clinical state within two hours; within four hours his mental state improved and at $\mathbf{2 4}$ hours he was fully alert and orientated, and was apyrexial.

We believe this case illustrates that the neuroleptic maligant syndrome is a clinical diagnosis and the abscence of an elevated creatine kinase does not exclude the condition. In the management of the confused patient taking neuroleptic medication the clinician must have a high index of suspicion for making this diagnoses.

REMA SINGH Department of Neurology Atkinson Moreley Hospital, London, UK DELIAH HASSANALLY Department of Neurosurgery, The Maudsley Hospital, London, UK

\section{Learning points}

- neuroleptic malignant syndrome i underdiagnosed and carries a high mortality

- a high index of suspicion is essential

- exclude a septic focus

- stop all neuroleptics

- treat early with rehydration and intravenous dantrolene

- the dopamine agonists, amantadine bromocryptine, carbidopa/ levadopa may also be considered, benzodiazepines may help with muscle rigidity
1 Caroff SN. The neuroleptic malignant syndrome. f Clin Psychiatry 1980; 41: 79-83.

2 Caroff SN. The neuroleptic malignant syndrome. Psychopharmacol Bull 1988; 24: 25-9.

3 O'Dwyer AM, Shepherd NP. The role of creatine kinase in the diagnosis of neuroleptic malignant syndrome. Psychol Med 1993; 23: 323-6.

4 Caroff SN, Mann SC, Lazarus A. The neuroleptic malignant syndrome: diagnostic issues. Psychiat Ann 1991; 21: 130-47.

\section{Flavobacteriummeningosepticum} meningitis in an adult with acute leukaemia

Sir,

Flavobacterium meningosepticum is a Gramnegative bacillus, widely distributed in nature being found in water and moist areas. The hospital environment is often contaminated with this organism. It is an opportunist, causing epidemics in postnatal intensive care units and occasional sporadic cases. ${ }^{1}$ It frequently causes purulent meningitis in nonhospitalised children. ${ }^{2}$ Cases of infection in adults are rare and meningitis remains exceptional.

\section{Case report}

A 27-year-old man living in Niamey (Niger) was admitted to the intensive care unit with fever, pancytopenia, and localised cervical cellulitis. A diagnosis of acute myelogenous leukaemia (AML) of M1 subtype in the French/American/British classification was made. Septicaemia due to Pseudomonas aeruginosa was documented and the patient was treated with piperacillin, netilmicin and metronidazole, administered via an indwelling central venous catheter. When afebrile, induction chemotherapy was started with lomustine, doxorubicin and cytarabine. Two days after completion of chemotherapy, fever reappeared and he was empirically treated with vancomycin, amikacin and ceftazidim. On day 13, meningitis developed and a lumbar puncture was performed. Analysis showed abnormal cellularity with 160 white blood cells/ml, but normal glucose and protein levels. Three blood cultures and cerebrospinal fluid grew $F$ meningosepticum. In vitro bactericidal tests showed that rifampicin $(1 \mathrm{~g}$ intravenously every $12 \mathrm{~h})$, piperacillin $(6 \mathrm{~g}$ intravenously every $6 \mathrm{~h})$ and ciprofloxacin was the best association. On day 17 , aplasia resolved with rapid recovery of neutrophils. On day 19, the patient's neurological status was normalised. Fever rapidly resolved. Antibiotics were continued for 23 days. Repeated lumbar punctures remained without growth. Complete remission of AML was documented on day 22 after completion of chemotherapy. Early intensification treatment for AML was administered two weeks after antibiotic cessation.

In adults, $F$ meningosepticum is rarely pathogenic and is mainly responsible for nosocomial infections in immunosuppressed patients. ${ }^{1}$ Ten cases of $F$ meningosepticum adult meningitis have been described in the literature, in immunodeficient patients (polycythaemia vera, aplastic anaemia, disseminated tuberculosis, renal transplant, aplasia due to chemotherapy for acute lymphoblastic leukaemia, post-partum), ${ }^{3}$ or postsurgical (craniofacial or neurosurgical). ${ }^{4}$ One patient had no apparent immunodepression and died rapidly. ${ }^{5} F$ meningosepticum has a 
natural resistance to a number of antibiotics including those routinely bactericidal for Gram-negative bacilli, such as ampicillin, third-generation cephalosporins and aminoglycosides. It is usually susceptible to trimethoprim-sulfamethoxazole, imipenem and rifampicin. Among cases of adult meningitis, five immunosuppressed patients died and the four others were cured without ill effects. The seriousness of the disease is more from the terrain on which it occurs rather than the virulence of the germ. One patient without immunodepression with post-surgical meningitis was cured with monotherapy poorly penetratable to cerebrospinal fluid (CSF) or poorly bacteriostatic (amikacin for 13 days, then intravenous erythomycin for 25 days and the CSF cultures remaining positive for 25 days).

To our best knowledge, this is the first case report of an association between $F$ meningosepticum septicaemia and bacterial meningitis in a patient with AML. Our patient could have been an healthy carrier of $F$ meningosepticum, which became highly pathogenic because of persistent neutropenia. The favourable outcome underlines the need for early introduction of appropriate antibiotic therapy and the role of haematological remission in cure without sequelae.

$S$ KREBS

P BLANCHE

D BOUSCARY

E GAUTHER

F DREYFUS

D SICARD

Service de Medecine Interne

H BLANCHARD

Service de Bactériologie,

Hopital Cochin, Paris, France

Correspondence to $\mathrm{Dr}$ Blanche, Service de Médecine Interne, Hôpital Cochin, 27 rue du Faubourg St Jacques, 75679 Paris Cedex 14, France

1 McGowan JE, Del Rio C. In: Mandell GL, Douglas RG, Benett JE. Principles and practice of infectious diseases. 3rd edn. 1992; p 1790.

2 Kokindombo PO, Nko'o Amvenne S, Ndjtoyap Ndam EC, et al. Meningites purulentes à Flavobacterium meningosepticum chez l'enfant Camerounais. Ann Pédiatr 1991; 38: 491-5.

3 Rios I, Klimek JJ, Maderazo E, Quintelliana R. Flavobacterium meningosepticum meningitis report of selected aspects. Antimicrob Agents Chemother 1978; 14: 444-7.

4 Harrington SP, Perlino CA. Flavobacterium meningosepticum sepsis disease due to bacteria meningosepticum sepsis disease due to bacteria with unusual antibiotic

5 Uchihera T, Yokota T, Watabiki S, Veki M, Uchihera T, Yokota T, Watabiki S, Veki M,
Miyake S. Flavobacterium meningosepticum Miyake S. Flavobacterium meningosepticum
meningitis in an adult. $A m \neq \mathrm{Med} 1988 ; 85$ : 738-9.

\section{Eikenella corrodens thumb osteomyelitis}

Sir,

Eikenella corrodens is a small, facultatively anaerobic and slowly growing Gram-negative rod, ${ }^{1}$ which is a common inhabitant of the human oral cavity, upper respiratory, gastrointestinal and genitourinary tracts. ${ }^{2,3}$ It has been implicated in periodontitis, human wound infections and more serious diseases. ${ }^{3-8}$ We present a case of osteomyelitis of the terminal phalanx from the left thumb caused by $E$ corrodens.
Case report

A 55-year-old man was working in his garden when he injured his left thumb with a stone. He licked his finger to relieve pain. Five days later, he presented with left thumb nail bed haematoma, finger pain and fever. On examination he was pyrexial $\left(37.8^{\circ} \mathrm{C}\right)$ and had a tender, swelling, left thumb with subcuticular abscess of the nail folds. X-Ray examination was normal. The nail was removed and amoxicillin/clavulanic acid $(500 / 125 \mathrm{mg}$ tid) was prescribed for 10 days. Two weeks later he remained febrile $\left(37.5^{\circ} \mathrm{C}\right)$, and had left thumb pain and swelling. Radiographic examination revealed lytic bone defects on the terminal phalanx of the left thumb and soft-tissue swelling. The terminal phalanx was amputated. The operative material showed an acute suppurative response and necrosis of tissue. Culture of the bone yielded, three days later, heavy growth of $E$ corrodens. The pathogen was susceptible in vitro to penicillin, ampicillin, and tetracycline and resistant to clindamycin, cephalosporins, chloramphenicol and gentamicin. Amoxicillin, $500 \mathrm{mg}$ tid, was prescribed for 14 days. The wound healed quickly and all symptoms promptly subsided.

As $E$ corrodens is an endogenous oral bacterium it is not surprising that the most common clinical sources of this organisms are human bite wounds, head and neck infections and respiratory tract infections. Several clinical manifestations including soft-tissue infections or osteomyelitis caused by this organism, have also been described. Thus, most infections caused by $E$ corrodens involve areas contaminated by oral secretions. ${ }^{9,10}$ Probably, in our patient, the organism was inoculated when he licked his finger. It is a matter for speculation why amoxicillin/ clavulanic acid failed to cure the process or halt the development of osteomyelitis, in spite of the fact that the organism was susceptible in vitro to ampicillin. Presumably the daily dose and length of treatment were not sufficient to cure the infection, especially if osteomyelitis were already present when the patient was seen for the first time.

M CUENCA-ESTRELLA, JM RAMOS, J ESTEBAN, F SORIANO

Department of Clinical Microbiology JV VALLEJO

Department of Orthopedic Surgery, Fundación fimenéz Diaz, Madrid, Spain

Correspondence to J Esteban, Department of Medical Microbiology, Fundacion Jimenez Diaz, Avda Reyes Catolicos 2, 28040 Madrid, Spain

1 Eiken M. Studies on an anaerobic, rod-shaped, gram-negative microorganism: Bacteroides corrodens N. Sp. Acta Pathol Microbiol Scand 1958; 43: 404-16.

2 Jackson FL, Goodman Y. Genus Eikenella. In: Krieg NR, Holt JG (eds). Bergey's Manual of rystemic bacteriol (eds). Bergey's Manual of Wystemic bacteriology. Bal

3 Perez-Trallero E, Arenzana JMG, Eguiluz GC, De Toro Rios P. Extraoral origin of Eikenella De Toro Rios P. Extraoral origin of Eikenella
corrodens infections. Lancet 1988; 1: 298-9.

4 Suwanagool S, Rothkopf MM, Smith SM LeBlance D, Eng R. Pathogenicity of Eikenella LeBlance D, Eng R. Pathogenicity of Eikenella
corrodens in humans. Arch Intern Med 1983; 143: corrodens

5 Ramos JM, Pacho E, Garcia-Valle B, CuencaEstrella M, Franco A, Pontes MC. Splenic abscess due to Eikenella corrodens. Postgrad Med f 1994; 70: 848-9.
6 Joshi N, O'Bryan T, Appelbaum PC. Pleuropulmonary infections caused by Eikenella corrodens. Rev Infect Dis 1991; 13: 1207-12.

7 Stein A, Teysseire N, Capobianco C, Bricot R Raoult D. Eikenella corrodens, a rare cause of pancreatic abscess: two case reports and review. plin Infect Dis 1993; 17: 273-5.

8 Pollner JH, Khan A, Tuazon CU. Severe softtissue infection caused by Eikenella corrodens. Clin Infect Dis 1992; 15: 740-1.

9 Peeples E, Boswick JA Jr, Scott FA. Wounds of the hand contaminated by human or animal saliva. F Trauma 1980; 20: 393.

10 Schmidt DR, Heckman JD. Eikenella corrodens in human bite infections of the hand. $\mathcal{F}$ Trauma 1983; 23: 478 .

\section{Pressor effect of metoclopramide} in phaeochromocytoma

Sir,

Metoclopramide is a widely used anti-emetic in hospital practice. Apart from its well known extrapyramidal side-effects it is generally well tolerated. It has a little known pressor effect in normal individuals but can produce a massive rise of blood pressure in phaeochromocytoma. We describe a patient with phaeochromocytoma given metoclopramide where, fortunately, the outcome was good.

\section{Case report}

A 34-year-old woman, with recently diagnosed hypertension and a past history of neurofibromatosis Type I, was referred with episodic dizziness, sweating, recurrent headaches and nausea. Her blood pressure was initially $208 / 134 \mathrm{mmHg}$. Control of blood pressure had been poor over the past few weeks, despite nifedipine and atenolol prescribed by her general practitioner. On admission to hospital her blood pressure was $150 / 90 \mathrm{mmHg}$. Multiple café au lait spots and axillary freckling were noted. She had had a right below-knee amputation some years previously- for neurofibromatosis. Fundoscopy revealed grade III hypertensive changes. Physical examination was otherwise normal. Shortly after admission she complained of severe nausea and vomited once. She was given intramuscular metoclopramide $(10 \mathrm{mg})$. Within minutes the patient became profoundly unwell, clammy, pale, and vomited again. Her blood pressure rose to $280 / 160 \mathrm{mmHg}$. Intravenous labetalol $(50 \mathrm{mg})$ was infused over several minutes, which relieved her symptoms and lowered the blood pressure to $160 / 120 \mathrm{mmHg}$. A presumptive diagnosis of phaeochromocytoma was made and the patient was given an alpha-blocker, doxazosin, in addition to the $\beta$-blocker, atenolol. Nifedipine was discontinued on admission. Computed tomography (CT) scan of the abdomen revealed a $9 \times 7 \mathrm{~cm}^{2}$ mass in the left adrenal gland. A 24-hour urine collection contained $80 \mu \mathrm{mol}$ of normetadrenaline (normal $<4 \mu \mathrm{mol}$ ) and more than $70 \mu \mathrm{mol}$ of metadrenaline (normal $<4 \mu \mathrm{mol}$ ). The patient underwent left adrenalectomy and histological examination of the tumour confirmed the diagnosis of phaeochromocytoma.

Metoclopramide-induced hypertensive crisis was first described in $1976 .{ }^{1}$ Later this effect was confirmed by controlled administration of the drug before and after adrenalectomy in two patients with phaeochromocytoma. ${ }^{2}$ The mechanism may relate to a $\mathrm{D}_{2}$ dopaminergic inhibitory effect on the adrenal medulla which is blocked by both metoclopramide 